\author{
УДК 811.161.2 \\ DOI 10.35433/2220-4555.17.2020.fil-2
}

Ірина Сус,

кандидат філологічних наук, молодший науковий співробітник відділу рукописів Львівської національної наукової бібліотеки України імені Василя Стефаника

irynasus2014@ukr.net

\title{
ДО ІСТОРІЇ УКРАЇНСЬКО-ПОЛЬСЬКОЇ ЛЕКСИКОГРАФІЇ ПЕРШОЇ ПОЛОВИНИ ХІХ СТ.
}

У статті розглянуто одинадиять друкованих і рукописних пам'яток українсько-польської лексикографії першої половини XIX cm. За способом представлення в них лексичного матеріалу виокремлено самостійні та притекстові лексикографічні праці. Проаналізовано макро- й мікроструктурні особливості пам'яток.

3'ясовано, щзо джерелами для укладання словників слугували лексикографічні праці, лексика української народнорозмовної мови та лексика зі збірки українських народних пісень. Першу групу пам'яток становлять друкований «Прирбчный словарь славєно-польскій ...» (Львів, 1830) Йосипа Левиџького та рукописні «Матеріяли до словаря русскаго 1822-1826» Івана Лаврівського, «Словарь языка южно-руского 1834-1844» Івана Вагилевича, «Матеріяли до руского словаря» Йосипа Скоморовського.

Другу групу складають пам'ятки притекстової лексикографії. У більшості ицих джерел українська лексика зафіксована польською графікою. "Stowniczek mniej zrozumiatych słów ruskich» представлений у додатку до збірки «Pieśni ludu ruskiego w Galicyi» (Львів, 1839-

40) Паулі Ітнація Жетоти. У друкованих та рукописних наукових працях I. Вагилевича вміщено шість українсько-польських словничків. 3-поміж них одна фразеографічна пам'ятка «Idyotyzту»-частина рукописної монографіï «Rozprawy о języku poludnioworuskim». В етнографічних розвідках «Hисułowie. Mieszkańcy wschodniego wzgorza Karpat», «Bojki, szczep rusko-słowiański w Galicyi», «Łemki. Mieszkańcy zachodniego wzgorza Karpat» I. Вагилевича вміщено гуиульський (друкований та рукописний варіанти), бойківський (два рукописні варіанти), лемківський (рукописний) словнички з польськими відповідниками.

Ключові слова: украӥнсько-польська лексикографія першої половини ХІХ ст., друкований словник, рукописний словник, притекстова лексикографія, макро- й мікроструктура словника.

\section{Iryna Sus. Do historii ukraińsko-polskiej leksykografii z pierwszej połowy XIX w.}

Przebadano jedenaście drukowanych i rękopiśmiennych zabytków leksykografii ukraińsko-polskiej z pierwszej połowy XIX wieku. W sposób, w który został przedstawiony materiałleksykalny, wyróżniono odrębne i przytekstowe prace leksykograficzne. Analizowane są makrostrukturalne $i$ mikrostrukturalne cechy szególne zabytków.

Słwa kluczowe: leksykografia ukraińsko-polska z pierwszej połowy XIX wieku, słownik drukowany, słownik rękopiśmienny, leksykografia przytekstowa, makrostruktura i mikrostruktura słownika.

\section{Sus Iryna. To the history of ukrainian-polish lexicography of the first part of the $19^{\text {th }}$ century}

The paper studies eleven printed and handwritten Ukrainian-Polish lexicographic sources, including separate lexicographic works and glossaries. The peculiarities of macro- and microstructure of the dictionaries have been characterized. It has been proved that the lexicographic works served as sources for the compilation of "Dictionary of Ukrainian Live Folk Language" and "Dictionary of the Collection of Ukrainian Folk Songs". The first group 
consists of the independent lexicographic works: printed «Прир чиный словарь славєно-польскій ...» (The Handy Slavonic-Polish Dictionary ...; Lviv, 1830) by Yosyp Levytsky, and handwritten works «Mатеріяль до словаря русскаго» (Materials to the Ruthenian Dictionary; 1822-1826) by

Ivan Lavrivsky, «Словарь языка южно-русского» (South Ruthenian Dictionary; 1834-1844) by Ivan Vahylevych, «Mатеріяль до руского словаря» (Materials to the Ruthenian Dictionary) by Yosyp Skomorovsky.

The second group consists of Ukrainian-Polish sources of the glossary lexicography. The Ukrainian vocabulary was represented by Polish graphics in most of the sources. Ukrainian-Polish «Stowniczek mniej zrozumiatych stów ruskich» was included into annexes to the collection «Pieśni ludu ruskiego w Galiciji» (1839-1840) by Pauli Żegota. I. Vahylevych's ethnographic studies «Hucułowie. Mieszkańcy wschodniego wzgórza Karpat», «Boyki, szczep rusko-słowiański w Galicyi», «Łemki. Mieszkańcy zachodniego wzgórza Karpat» contained five glossaries: printed and handwritten Hutsul variants, two handwritten Boyko variants, and handwritten Lemko glossary. The phraseographic work «Idyotyzmy» was part of his monograph «Rozprawy o jezzyku potudniowo-ruskim».

Key words: Ukrainian-Polish lexicography of the first part of the $19^{\text {th }}$ century, printed dictionary, handwritten dictionary, glossary, macrostructure and microstructure of dictionary.

Постановка проблеми та аналіз останніх досліджень і публікацій. В історії української перекладної лексикографії першої половини ХIX ст. малодослідженою ділянкою залишаються українсько-польські пам'ятки. Мовознавці досі зосереджували увагу на характеристиці окремих словників або деяких мовних явищ у них. Зокрема діалектну лексику зі «Словаря языка южно-руского» I. Вагилевича Б. Галас використовує для зіставлень з іншими словниковими матеріалами того часу [8, с. 87-97]. А. Будзяк підготувала до друку «Словарь ...» I. Вагилевича у виданні «Rękopiśmienna spuścizna słownikarska Iwana Wahylewycza» (Краків, 2014), схарактеризувавши в пам'ятці макро- й мікроструктуру, правопис, діалектні фонетичні та морфологічні риси української лексики, запозичення до української мови, українську народну лексику на позначення фауни [1, s. 51-60; 2, с. 26-33; 23, s. 108-410].

Б. Галас у «Матеріялах до руского словаря» Й. Скоморовського проаналізував фонетичні, морфонологічні та лексичні явища, властиві карпатському регіону [7, с. 48-58; 9, с. 185-191; 10 , с. $57-59 ; 10$, с. $128-137]$.

Словничок в опублікованій етнографічній розвідці «Hucuły, mieszkańcy wschodniego wzgórza Karpat» I. Вагилевича вперше розглянув Я. Янув у статті «Słownik huculski spred stulecia», зазначивши про неточно передані польські відповідники [25, s. 3-12]. Топографічні назви - апелятиви, зафіксовані I. Вагилевичем у словничках-додатках до етнографічних розвідок про бойків, гуцулів та лемків, вивчала А. Будзяк [4, с. 35-45]. П. Горецький проаналізував окремі макро- й мікроструктурні особливості «Słowniczka mniej zrozumiałych słów ruskich» П.-І. Жеготи [12, с. 54-55].

Рукописний українсько-польський фразеологічний словничок «Idyotyzmy» підготував до друку Й. Дзендзелівський у 1979 р. [5]. Лексико-граматичні розряди фразеологізмів в пам'ятці визначила Л. Ткач [22, с. 277-292]. А. Будзяк виявила в «Idyotyzm»-ах українські фразеологізми 3 компонентами польського походження та виконала зіставлення фразеологічних одиниць пам'ятки, «Галицько-руських народних приповідок» I. Франка та «Фразеологічного словника української мови» (Київ, 1999) [3, с. 69-76; 24, s. 282].

«Прир४чный словарь славєно-польскій или собранїє рєчєній славєнскїхъ нє४добъ разимитєлныхъ обр баюцихъсл въ Книгахъ Церковныхъ на газыкъ польскій толкованыхъ» (Львів, 1830) Й. Левицького та «Матеріялы до словаря русскаго» І. Лаврівського не були об'єктом вивчення. 
Ірина Сус. До історії украӥнсько-польської лексикографії першої половини ХІХ ст.

Мета статті - систематизувати українсько-польські друковані й рукописні лексикографічні пам’ятки першої половини XIX ст. та описати їхні макро- й мікроструктурні характеристики.

Методи дослідження. У дослідженні використано структурний метод для аналізу макрой мікроструктури пам'яток, метод компонентного аналізу - для класифікації фразеологічних одиниць. За допомогою прийому кількісних підрахунків установлено кількість онімів та фразем у словниках.

Виклад основного матеріалу. Українсько-польські лексикографічні пам'ятки першої половини XIX ст. становлять одинадцять друкованих та рукописних джерел. За способом представлення лексичного матеріалу це $\epsilon$ самостійні та притекстові лексикографічні праці.

Самостійні лексикографічні праці репрезентують чотири українсько-польські пам'ятки. 3поміж них одна друкована - «Прир४чный словарь славєно-польскій ...» (Львів, 1830) грекокатолицького священника, українського мовознавця, поета, перекладача, публіциста Й. Левицького [15].

У передмові до «Прир૪чного словаря славєно-польского ...» Й. Левицький визначив його завдання: «собрати самыл тр४дньйшїл слова обрҺтающї̈лсл въ книгахъ цєрковныхъ, бєзъ которыхъ разУмЊнїл найпаче СвАџєнницы нємогУтъ никакимъ образомъ словесно шдавати чєсть и приносити молєнїл Бог४» [17, с. IV]. I. Огієнко зазначив, що «Прир४чный словарь славєно-польскій ...» надрукований для потреб духовенства Галичини в час його найбільшої полонізації [19, с. 125].

До макроструктури «Прир४чного словаря славєно-польского ...» увійшло 4500 слів церковнослов'янської мови української редакції: апелятиви та спорадично - оніми, зокрема хрематоніми: Аканөїсть (с. 1), Антологїонь (с. 3), Єvхологїй (с. 21); теонім Господь (с. 16); міфоніми: Колєда (с. 35), Кชпало (с. 42). Мікроструктура словника містить граматичну інформацію, зокрема числову характеристику іменників, що вживаються лише у формі мн.: надраги (множ. числ.) (с. 49), надры (множ. числ.) (с. 49); у прикметниках й дієприкметниках - закінчення ж. і с. р.: пособивый -ал, -оє (с. 89), слАкій, -ал, -оє (с. 116), постижєн, -жна, -жно (арк. 89), собиратєльный, совок питтєльный -аА, -оє (с. 117). Значення заголовних слів передано польськими однослівними відповідниками: ничто́жє 'nic' (c. 64), námєрuщ̧a 'pastoral' (с. 80), сєлó 'pole' (с. 113); описовими конструкціями: Си́ли 'nazwisko aniołów drugiego stopnia' (c. 113), соть 'płaster miodu' (c. 120).

Цією пам'яткою Й. Левицький продовжив традицію створення «словено-польських» словників, виданих у Супраслі в 1722 р. та в Почаєві в 1751, 1756, 1804 pp. [15, с. 78]. На підставі зіставлення макро- й мікроструктури «Прир४чного словаря славєно-польского ...» та його лексикографічного джерела «Лєฎૂікона сиръчъ словёсника славёнского, имЊющь в себъ словеса первыє славенскія азбучныя, посемъ же полскія» (Почаїв, 1804) виявлено відмінності в обох пам'ятках. Зокрема макроструктура «Прир४чного словаря славєно-польского ...» доповнена мовознавчими термінами: dїєnричастїє 'imiesłow, (gerundium)' (c. 19), naдєжъ 'w gramatyce spadek (casus)' (с. 78); церковно-релігійними термінами: пасхалї̈ 'tablica z której wielkanoc i inne święta od wielkanocy zawisłe dojść można (c. 80), хиротонїa 'położenie rąk' (c. 140); біблійною лексикою: динарій 'cztery lub tylko dwie drachmy, moneta żydowska' (c. 17), идоль (грєч. рєч.) 'bałwan, bożyszcze' (с. 33); мікроструктура розширена етимологічною характеристикою заголовних слів: дора (грєч. рєч.) 'dar' (c. 18), єламъ (грєч. рєч.) 'młodzieniec'(c. 20) та інформацією про лексико-граматичні розряди займенників, прислівників: азъ (мєстоим.) ‘ja’ (с. 1), до косна (наръч.) ‘do poźna’ (c. 18).

Авторами рукописних джерел цієї групи були провідники національного відродження в Галичині. Першу пам'ятку - українсько-польсько-німецький словник «Матеріялы до словаря русскаго» в 1822-1826 pp. уклав I. Лаврівський, греко-католицький священник, доктор богослов'я й філософії [11, с. 50; 16].

Макроструктуру словника становлять близько 22500 слів, однак він не повний: у першому томі - матеріал на літери Б, В; у другому - на Д, С, Ж; у третьому - на 3, у 
четвертому - на Л, М; у п’ятому - на С; у шостому - на $\Phi$, Ч. Лексикографічним джерелом для «Матеріялів ...» слугував один із авторитетних словників того часу - «Słownik języka polskiego» (1807-1814) Б.-С. Лінде [26].

До макроструктури «Матеріялів ...» уведено апелятиви та 77 онімів, зокрема антропоніми: Mapis, (4, арк. 104), Савина (5, арк. 21), Барановскї̈и (1, арк. 26 зв.); полісоніми: Бонон ъа (1, арк. 129), Добромиль (2, арк. 49 зв.); хороніми: Буковина (1, арк. 159 зв.), Сербил (5, арк. 34 зв.), Франиіа (6, арк. 31); гідроніми: Бъгъ (1, арк. 158 зв.), Дн тстръ (2, арк. 42 зв.), Донець (2, арк. 84) та ін.

У мікроструктурі пам'ятки загаловні слова мають граматичну характеристику українською або польською мовами - в іменників рід та закінчення Р. в. одн.: ба́ль 'bal, -u, m.' (1, арк. 12 зв.), бєрєза 'brzoza -y, ż' (1, арк. 153), смола 'smoła, -y, ż.' (5, арк. 90 зв.); у прикметників закінчення ж. та с. р.: выгодный 'wygodny, -a, -е' (1, арк. 272 зв.), старый 'stary, -a, -e' (5, арк. 160 зв.) та іншу етимологічну характеристику: вилїл 'Wiliia, Wigiliia, -ii, ż. z łac. dzień swięto poprzedzaiący, przedswięcie, der Vorabend' (1, арк. 218), мониторъ 'Monitor, -a, m. z łacin.: napominacz, postrzegacz' (4, арк. 141 зв.) тощо.

I. Лаврівський для передавання значень заголовних слів використовує польські однослівні відповідники: брлскъ 'brzask' (1, арк. 149 зв.), довжина 'dłużyna' (2, арк. 41 зв.), сатиричный 'satyryczny' (5, арк. 20) та описові конструкції українською й польською мовами: спорышь 'sporysz, зєрно в жит' чо́рнє, вєликє' (5, арк. 128 зв.), чєканєц̧ь, -нца m. 'ten, co czeka na promocyą, kandydat' (6, арк. 83), чаманага -и, f. 'gatunek sztuki mięsa ormiańskiey, wprzody kilku dniami marynowany w saletrze i w róznych ziołach, czamanaga' $(6$, арк. 53 зв.) та ін.

У пам'ятці подано ілюстрації українською або польською мовами, переважно взяті зі «Słownika języka polskiego» С.-Б. Лінде, часто 3 паспортизацією: чєрвонакъ, чєрвоногъ, римллне збытки поповнАючи' зъ самихъ газико̃въ чєрвоного̃въ робили потрав४. Sen. List. 4. 47. Plin. H. N. 10. 48. Обыйдє сл бєзъ газико̃въ чєрвонако̃въ Sen. List. 4. 47. [X. Pawida Pilchowskiego Sallustyusz Seneki Listy. 8. 4 Voll]. [26, s. 368]; також із українського народного мовлення: чєрндвость - чєрєсь тот8 бълость нєдобрь пєрєбивать сл гакась чєрнавость (6, арк. 99-100), чєрвєнєиь - оу ніого тислча чєрвоньчиковъ, гакъ ничъ, п४стить Њхъ на єдєнъ дєнь (6, арк.111); з-поміж них - фраземи: бакї - бакї ком४ св'тити 'baki komu świecić' (1, арк. 11), завєрєчи - завєрєчи комУ чимъ очы 'zarzucić komy czym осzy', завєрєчи мУ чо въ очы 'zarzucić komy co w oczy' (3, арк. 90); часъ - по час` р४синъ м४дрый (6, арк. 69).

Услід за І. Лаврівським українсько-польські словники укладали учасники народознавчого гуртка «Руська трійця» І. Вагилевич та Й. Скоморовський. Діячі «Руської трійці» записували народнорозмовну мову під час започаткованих ними етнографічних експедицій Галичиною, Буковиною та Закарпаттям. Ці лексичні матеріали слугували джерелами для словників української мови [14, с. 89].

I. Вагилевич планував укласти «Словарь языка южно-руского» за зразком словника сербської мови Вука Караджича: з граматикою та описом обрядів і переказів українського народу [20, с. 7]. «Словарь ...» - українсько-польсько-німецько-латинський словник, макроструктура його складає понад 10000 заголовних слів, укладених за алфавітом [6]. Словник не завершений: близько 6100 слів заголовних слів мають іншомовні відповідники, зокрема на літери A-E містяться матеріали кожною із вказаних чотирьох мов. Заголовні слова на Ж-О мають переважно польські й рідше німецькі відповідники, а латинські трапляються лише спорадично. Матеріали від літери П і до кінця рукопису - це здебільшого список лише українських слів.

Макроструктуру пам'ятки становлять апелятиви й оніми (27 назв) української народнорозмовної мови, серед яких переважають хороніми: Волинє (арк. 20), Запорожє (арк. 68), Польщєє (арк. 134), Украй ъна (арк. 195) та міфоніми: Дазьбіг (арк. 35), Купало (арк. 86), Магора (арк. 93), Перун (арк. 125) та ін.

У мікроструктурі «Словаря ...» заголовні слова здебільшого пояснені польськими однослівними відповідниками байка 'bajka' (арк. 4), боронити 'bronic' (арк. 7), домівка 
Ірина Сус. До історії українсько-польської лексикографії першої половини ХІХ ст.

'pomieszkanie' (арк. 38). Описовими конструкціями головно українською мовою пояснено безеквівалентну лексику - назви на позначення орографічних об'єктів, етноніми, назви народного одягу та прикрас, назви танців та ігор, назви обрядових пісень: безкиди 'звичайне пр'ззище руских Карпатів' (арк. 5), бойки 'горєни руск中 мешкають в Карпатах від кирниць Сана до Льтниц'' (арк. 7), киптарь 'горєнський куртий кожух вишиваний без рукав' (арк. 78), ланка 'zawiązka na szyi' (арк. 88), коломийка 'танец м'сцевий молодь обой проти твере круги обручают сє и розсипают сє по рати, а плясаючий и єго товаришка приспьвуют

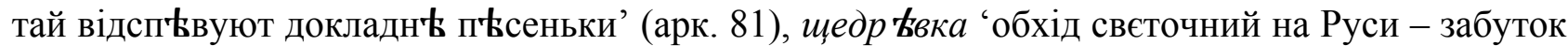

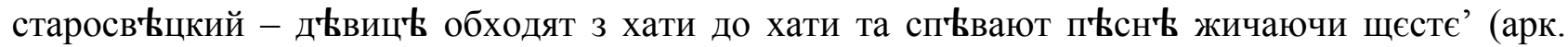
214) та ін.

Серед діячів «Руської трійці» одним із найактивніших збирачів матеріалу до словника української народної мови був Йосиф Скоморовський (1819-1891), греко-католицький священник на Тернопільщині. На основі своїх записів та збірок лексичного матеріалу інших учасників народознавчого гуртка Й. Скоморовський уклав п'ятитомний українськопольський словник «Матеріялы до руского словаря» [14, с. 29, 79-80; 21].

Макроструктуру «Матеріялів ...» становлять понад 27000 заголовних слів: апелятивна лексика та 88 онімів. Найбільше 3-поміж них антропонімів (65 назв), які автор подає в нормативному та розмовно-побутовому варіантах: Га́нна, Ган ४нька, Ган ४ся, Ган ४ська (1, арк. 121 зв.), Илько (2, арк. 128), Назар (2, арк. 93), Oстап (4, арк. 174 зв.); андроніми: Ильчиха (2, арк. 128), Марчиха (3, 65 зв.), Стасиха; хороніми: Аме́рика (1, арк. 5), Галиціа (1, арк. 120 зв), Франція (5, арк. 142), Угерщина (5, арк. 115 зв.); геортоніми: Јорданьскіjі свята (2, арк. 137 зв.), Кв ътна нед қля (3, арк. 19 зв.), Успеніе (5, арк. 131); хрематоніми: Акафист (1, арк. 3 зв.), Апостол (1, арк. 6), Молебен (3, арк. 75).

У мікроструктурі «Матеріялів ...» лексикограф поєднує різні способи характеристики й перекладу заголовних слів. У словнику на дво- й більшескладових заголовних словах позначено наголос. Після заголовного слова подано граматичну характеристику латинською мовою: в іменників рід - anémum, m.[asculinum] (1, арк. 6), ака́ц̧ia, f.[emininum] (1, арк. 3 зв.), јагня, n.[eutrum] 'jagnię’' (2, арк. 131); число іменників - ácmpu, pl.[urālis] (1, арк. 7), бра́тчики, pl.[urālis] (1, арк. 30); у прикметників, займенників, прислівників, сполучників, прийменників - частиномовну приналежність: аксамито́виj, adj.[ectīvum] (1, арк. 3 зв.), по ара́бски, adv.[erbium] (1, арк. 6), ти, pron.[ōmen] (5, арк. 101), a, conj.[unctio] (1, арк. 1).

Переклад заголовних слів виконано кількома способами - однослівними відповідниками: арендова́ти 'arendować' (1, арк. 6), бо́ронити 'bronić' (1, арк. 28), вiдл 'ъта́ти 'odlatywać' (1, арк. 89), аллил צja 'alleluja' (1, арк. 4); синонімними еквівалентами: го́д t' 'dosyć, koniec, po wszystkiem, daremnie, na prózno' (1, арк. 129 зв), красно́ 'ładnie, pięknie’ (3, арк. 31 зв.), ла́zодити 'sporządkać, łagodzić, przysposabiać' (3, арк. 45); описовими конструкціями українською або польською мовами здебільшого передано безеквівалентну лексику церковно-обрядові назви: Ака́фист 'akafist, rodzaj nabożeństwa cerkiewnego, na cześć Pana Jesusa, Najśw. Bogarodzicy, jako też innych Swiętych, ułożonego' (1, арк. 3 зв.), Апо́стол, 'apostoł, księga zawierająca dzieje i listy apostolskie, lekcya, która sie pod czas mszy czyta z tejże księgi' (1, арк. 6); етнографічні назви: гајівка, 'zabawa, którą lud wyprawia we Swięta wielkonocne (zwykle koło Cerkwi)' (1, арк. 120), вечернии 'ъ, pl. 'także вечłрки, pl. wieczornice, wieczórki (schadzki młodzieży wiejskiej pod czas długich zimowych wieczorów) ходити на вечерниц'‘' (1, арк. 43); пояснення значень вигуків і часток: аво́н, аво́нде, аво́ндејка, аво́ндечка 'oto tam (pokazując na przedmiot odległejszy)' (1, арк. 1-1 зв.), аво́сь, аво́сьде, аво́сьдејка, аво́сьдечка 'oto tutaj (wskazując na przedmiot w bliskości będący)' (1, арк. 1 зв.), а 'wykrzyknik, wyrażający podziwienie' (1, арк. 7 зв.) та ін.

У мікроструктурі пам'ятки як ілюстрації до заголовних слів подано українські фраземи. Їхні значення передано польськими еквівалентами або поясненнями: ба́ки забити кому' 'bakę zabić komu, zabałamucić kogo' (1, арк. 10 зв.), вибити собһ щео з голови 'wybić sobie со z głowy' (1, арк. 46), земля на него дпа́ла 'росzerniał jak ziemia' (2, арк. 108), ходити хо́дором за 
ким 'chodzić za kim nieustannie krok w krok' (5, арк. 150). Використано також ілюстрації 3 фольклору: відкропитися - свяче́ною водо́ю не відкро́пишся від не́го (1, арк. 88 зв.); ді́mu -

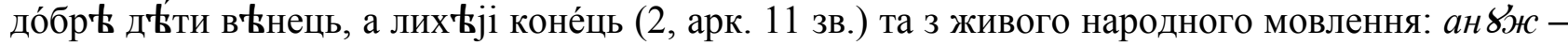
ан४ж јего́ не застанемо до́ма, що тогди зро́бимо? (1, арк. 5), ладити ся - господарство не ладит ми ся так, јак треба (3, арк. 46).

У кінці XVIII - на початку XIX ст. в українському словникарстві сформувалася притекстова лексикографія, «невеликого обсягу словники, написані новою українською літературною мовою, виходили як додатки до збірок народних пісень, художніх творів чи граматик» [12, с. 36-37]. Такі словнички як додатки до творів, на думку I. Матвіяса, поява була важливим чинником у нормуванні української лексики в першій половині XIX ст., оскільки діалектна лексика тоді сприймалася як складова частина лексичного фонду літературної мови [18, с. 146-147]. В історії українсько-польської лексикографії першою пам'яткою українсько-польської притекстової лексикографіï $\epsilon$ «Słowniczek mniej zrozumiałych słów ruskich» у додатку до другого тому збірки «Pieśni ludu ruskiego w Galicyi» (Lwów, 1839-40 pp.) Паулі Ігнація Жеготи (1814-1895) - фольклориста, етнографа та історіографа, дослідника й видавця польської та української народнопоетичної творчості [13, c. $255 ; 32$, s. 207-214].

Макроструктуру пам'ятки становить близько 650 заголовних слів, укладених за алфавітом польської мови й переданих польськими літерами. Значення заголовних слів пояснено польськими однослівними відповідниками: barysz 'zysk' (s. 207), besida 'rozmowa' (s. 207), dumaty 'myśleć' (s. 208); синонімними еквівалентами: derewnia 'izba, dom, chata' (s. 208), neduha 'niemocz, choroba' (s. 211); безеквівалентну лексику - описовими конструкціями: arszyn 'miara, mająca blisko 5 cwierći łokcia polskiego' (s. 207), oranycia 'pole poorane' (s. 211), litnyk (ukr.[aińskie]) 'suknia letnia kobieca' (s. 210), sotnia 'kupa ludzi składajaca się ze sta' (s. 214). До близько 20 відсотків заголовних слів подано етимологічну характеристику: bidniak serb.[skie] 'bednik' (s. 207), goj żydowsk.[ie] 'newerny' (s. 209), woskres cerk.[iewne] 'z martwych wstał' (s. 216), fajnyj niemiec.[kie] 'tęgi' (s. 208), munycia włosk.[ie] 'zbroja' (s. 211), swojasy cerk.[iewne] 'dom swój' (s. 214), tałan tatarsk.[ie] 'szczęscie' (s. 215), trutynojka 'trucizna', staroruskie trut (s. 215); указано на приналежність слів до гуцульських говірок: cziczka huculsk.[ie] 'kwiatek' (s. 208), krysanyna huculsk.[ie] 'kapeluch' (s. 210) та лексику, не поширену в Галичині: kudrawyj (s. 210), kurhan (s. 210), tyman (s. 210), tuczeb (s. 210).

У друкованих та рукописних наукових працях I. Вагилевича вміщено шість українськопольських словничків. 3-поміж них одна фразеографічна пам'ятка «Idyotyzmy» є частиною рукописної монографіï «Rozprawy o języku południowo-ruskim». Макроструктуру фразеологічного словничка становлять укладені за алфавітом 240 одиниць української народнорозмовної мови [5, с. 466-471]. Мікроструктуру пам'ятки формує заголовне слово народнорозмовна фразеологічна одиниця та польський відповідник-фразеологізм або пояснення польською мовою: ни с қло, ни пало 'ni stąd, ni z owąd' (c. 468), и гадки не маеть 'ani mu do głowy nie przyjdzie' (c. 468), не для его лица 'niestosownie' (c. 468), выкинуло го зъ памяти 'zapomniał o tem' (c. 467), тягу даль 'uciekł' (c. 470).

B «Idyotyzm»-ax представлено одиниці фразеотематичної групи «Людина» 3 фразеосемантичними полями «Фізичний стан особи»: мене мдлость обнимаетъ 'mdłości na mnie biją' (c. 468), онъ такъ попосн 'kı 'on tak zbladł' (c. 469); «Психічний стан особи»: душа въ мене вступила 'uspokoiłem się' (с. 467), спльль зъ розума 'zgłupiał' (c. 470); «Поведінка особи»: дивится зъ подлобья 'patrzy się ponuro' (с. 467), не загр $\mathbf{k} л ь$ м tстиа 'nie utrzymał się' (c. 468); «Стосунки між людьми»: въ козлой рогъ загнати 'przycisnąć' (c. 467), онъ кипитъ на него 'on odraża się na niego' (c. 469); фразеотематичної групи «Сприйняття навколишнього світу», що включає фразеосемантичні поля: «Абстрактні відношення і поняття»: дуже ся ладить 'bardzo odpowiednio' (с. 467), то не до притоки (цету) 'to się nie lączy' (c. 470); «Явища природи»: вода ся гонитъ 'woda się męci' (c. 466), дурна погода 'niepogoda' (c. 467); 
Ірина Сус. До історії украӥнсько-польської лексикографії першої половини ХІХ ст.

«Час»: вчера воточи (в тъи чинъ) 'wczora pod ten czas' (c. 466), за деле годъ 'w sam dobry czas' (c. 467).

У рукописних етнографічних розвідках «Hucułowie. Mieszkańcy wschodniego wzgorza Karpat», «Bojki, szczep rusko-słowiański w Galicyi», «Łemki. Mieszkańcy zachodniego wzgorza Karpat» I. Вагилевича вміщено гуцульський (196 слів), бойківський (172 слова), лемківський (48 слів) словнички з польськими відповідниками. Ці праці зберігаються в Бібліотеці РАН у Санкт-Петербурзі, їхні копії - у Науковій бібліотеці Львівського національного університету ім. I. Франка $[27 ; 29 ; 30]$. Ще один варіант гуцульського словничка (93 слова) надрукований у польському часописі «Przegląd naukowy» (Варшава, 1844) [31]; варіант бойківського словничка (146 слів) зберігається у Львівській національній науковій бібліотеці В. Стефаника [28].

Українська лексика пам'яток зафіксована польською графікою: sawaty 'dokuczać' (19, s. 25), lelekczy 'siać sitkiem' (18, s. 25;19, s. 24), rin 'drobny rzéczny piasek' (18, s. 23;19, s. 25), bludo 'misa' (16, s. 19;17, s. 18), ilczystyj 'cienki' (16, s. 20; 17, s. 18), hrada 'nasep z hrubego piasku' (16, s. 20), obitnie 'obiad zaduszny' (16, s. 20; 17, s. 19). У кінці гуцульського, бойківського, лемківського словничків подано оніми - антропоніми, топоніми, гідроніми, мікроороніми.

Висновки. Українсько-польські лексикографічні праці першої половини XIX ст. - це пам'ятки перекладного та перекладно-тлумачного типу, 3-поміж них - фразеографічний та діалектні словнички. У проаналізованих пам'ятках виявлено мікроструктуру різного складу: за характеристикою заголовних слів - фонетичну, граматичну, етимологічну, ареальну інформацію; за способом їх перекладу - польськими однослівними, кількома синонімними еквівалентами, описовими конструкціями; за репрезентацією значення слова в контексті ілюстративний матеріал, за цитованістю матеріалу - паспортизацію. Найповнішу мікроструктурну характеристику заголовних слів містять самостійні лексикографічні праці, зокрема «Матеріялы ...» І. Лаврівського та Й. Скоморовського.

Перспектива дослідження. Лексичний матеріал українсько-польських пам'яток першої половини XIX ст. становить джерельну базу для студій української історичної лексикології, ономастики, фразеології, діалектології, українсько-польських мовних контактів.

\section{Список використаних джерел та літератури}

1. Будзяк А. Апелятивні назви тварин у рукописних словниках Івана Вагилевича. Beiträge der Europäischen Slavistichen Linguistik (Polyslav) 18 / herausgegeben von E. Guttiérez Rubbio, M. Falkowska, E. Kislova, M. Stępień. München - Berlin - Leipzig - Washington, 2015. S. 51-60.

2. Будзяк А. Апелятивні назви тварин у рукописних словниках Івана Вагилевича (назви птахів). Studia Methodologica. Тернопіль, 2014. № 39. С. 26-33.

3. Будзяк А. Західноукраїнські фразеологічні одиниці в лексикографічних працях XIX ст. Ukrajinistika: minulost, př́tomnost, budoucnost. III. Jazyk: kolektivni monografie věnovaná 20 výročí zahájení výuky ukrajinštiny jako studijního oboru na Filozofické fakultě Masarykovy univerzity v Brně. Brno, 2015. S. 69-76.

4. Будзяк A. Карпатські топографічні назви в лексикографічних роботах Івана Вагилевича. W świecie Słowian. Szkice z dziejów leksykologii i leksykografii. Księga dedykowana Profesorowi Wiesławowi Witkowskiemu w osiemdziesiątą piątą rocznicę urodzin / pod red. H. Chodurskiej, A. Mażulis-Frydel, A. Radzik. Kraków : Oficyna Wydawnicza «Impuls», 2013. S. 33-45.

5. Вагилевич I. [Idyotyzmy]. Дзендзелівський Й. O. Українсько-польський фразеологічний словник І. Вагилевича. Його ж. Українське і слов'янське мовознавство : зб. пр. Львів : Атлас, 1996. С. 467-471 (Українознавча бібліотека НТШ. Ч. 6).

6. Вагилевич I. Словарь языка южно-руского 1834-1844 // Російська нац. б-ка. Санкт-Петербург. Ф. 16. Спр. 23. 218 арк.

7. Галас Б. 3 історії морфонологічних явищ української мови (на матеріалі рукописних словників ХІХ - початку ХХ ст.). Вісник Запорізького національного університету : зб. наук. ст. Філологічні науки. Запоріжжя, 2006. №. 2. С. 48-58.

8. Галас Б. К. Лексика гуцульських i буковинських говірок у записах I. Вагилевича та Я. Головацького. Слов'янська філологія : зб. наук. пр. Чернівці : Рута, 2000. Вип. 93. С. 87-97. 
9. Галас Б. К. Рукописні словники XIX - початку XX ст. і тенденції розвитку української літературної мови в Західній Україні. Матеріали Міжнародної асоиіації україністів (м. Чернівиі, 25-29 серпня 2002 р.). Чернівці : Рута, 2003. С. 185-191.

10. Галас Б. К. Українська народна географічна термінологія в рукописних словниках I половини XIX ст. Науково-технічний прогрес і проблеми термінології : тези доп. республ. конф. (м. Львів, травень 1980 р.). Київ : Наук. думка, 1980. С. 57-59.

11. Галас Б. К. Ф. С. Шимкевич як лексикограф і українське словникарство (кінець XVIII - початок ХХ ст.). Ужгород : Поличка «Карпатського краю», 1995. 300 с.

12. Горецький П. Й. Історія української лексикографії. Київ : Вид-во АН УРСР, 1963. 244 с.

13. Збир І. Український фольклор у розвідках польських дослідників на матеріалі «Покуття» Оскара Кольберга. Проблеми слов 'янознавства : наук. зб. Львів, 2005. Вип. 55. С. 254-262.

14. Кирчів Р. Етнографічно-фольклористична діяльність «Руської Трійці». Київ: Наук. думка, 1990. $344 \mathrm{c.}$

15. Кульчицька T. Українська лексикографія XIII-XX ст. : бібліографічний покажчик / наук. ред. Д. Г. Гринчишин. Львів, 1999. 360 с.

16. Лаврівський І. Матеріяли до словаря русскаго (1822-1826 pр.) : у 6 т. Львівська наи. наук. б-ка Украйни ім. В. Стефаника. Ф. 2. Оп. 1. Спр. 331. Т. 1: Б-В. 698 с.; Т. 2: Д, С, Ж. 520 с.; Т. 3: 3. 520 с.; Т. 4: Л-М. 196 с.; Т. 5: С. 480 с.; Т. 6: Ф,Ч. 400 с.

17. Левицький Й. Прир४чный слова́ръ славєно-по́льскій, или собра́нїє Рєчє́ній славє́нскїхъ нє४до́бъ

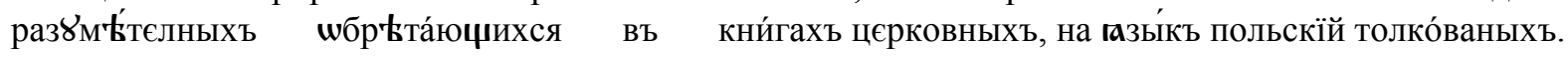
Лвигородъ, 1830. $148 \mathrm{c}$.

18. Матвіяс І. Г. Українська мова та їі говори. Київ : Наук. думка, 1990. 168 с.

19. Огієнко І. (Митрополит Іларіон). Історія української літературної мови / упоряд., автор іст.-біогр. нарису та приміт. М. С. Тимошик. Київ : Либідь, 1995. 296 с.

20. Переписка Івана Вагилевича. Матеріяли до історії украӥнсько-чеських взаємин в першій половині XIX cm. / видав I. Брик. Львів : Накладом НТШ, 1921. Розд. 1. С 1-32 (Українсько-руський архів. T. 15).

21. Скоморовський Й. Матеріялы до словаря руского : у 5 т. Львівська наи. наук. б-ка України ім. В. Стефаника. Ф. 77. Оп. 1. Спр. 305. Т. 1: А-Г. 146 арк.; Т. 2: Д-Й. 137 арк.; Т. 3: К-О. 181 арк.; Т. 4: П. 220 арк.; Т. 5: Р-Щ. 184 арк.

22. Ткач Л. Народнорозмовне джерело фразеологізмів спільного фонду української та польської мов. Українська історична та діалектна лексика : зб. наук. пр. Львів: Ін-т українознавства ім. І. Крип’якевича НАН України, 2003. Вип. 4. С. 277-292.

23. Budziak A. Rękopiśmienna spuścizna słownikarska Iwana Wahylewycza. Studia Ruthenica Cracoviensia. Kraków : Wyd-wo «Scriptum» 2014. № 8. $411 \mathrm{~s}$.

24. Budziak A. Zapożyczenia polskie w materiale ukraińskim XIX-wiecznego ukraińsko-polskiego słownika frazeologicznego Iwana Wahylewycza. Linguistica Copernicana. Toruń : Wyd-wo Nauk. Uniw. Mikołaja Kopernika, 2010. № 2 (4). S. 273-285.

25. Janów J. Słowniczek huculski sprzed stulecia. Lwów, 1937. Odbitka ze Sprawozdań Towarzystwa Naukowego we Lwowie. R.16. Z. 3. S. 1-12.

26. Linde S. B. Słownik jezzyka polskiego : t. 1-6 / red. M. Bańko, M. Majdak, M. Czeszewski. Warszawa : Drukarnia XX. Pijarów, 1807-1814. URL: $\underline{\text { http://www.leksyko }}$ grafia.uw.edu.pl/slowniki/37/slownik-jezyka-polskiego-warszawa-1807-1814 (дата звернення 07.10.2017).

27. Wagilewicz J. Narzecze. Łemki. Mieszkańcy zachodniego wzgorza Karpat. Lwów, 1841. Rozd. 5 // Наукова б-ка Львівського нац. ун-ту ім. І. Франка. М-1173. Копія.

28. Wagilewicz J. [Słowniczek]. Bojki. Szczep rusko-słowiański w Galicyi // Львівська нац. наук. б-ка України ім. В. Стефаника. Ф. 5. Оп. 1. Спр. 4342. С. 19-21.

29. Wagilewicz J. [Słowniczek]. Bojki, szczep rusko-słowiański w Galicyi. Lwów, 1839. S. 18-19// Наукова б-ка Львівського нац. ун-ту ім. І. Франка. М-1173. Копія.

30. Wagilewicz J. [Słowniczek]. Hucułowie. Mieszkańcy wschodniego wzgorza Karpat. Lwów, 1837. S. 22 23 // Наукова б-ка Львівського нац. ун-ту ім. І. Франка. М-1173. Копія.

31. Wagilewicz J. [Słowniczek]. O mieszkańcach wschodniej części gór Karpackich (dalszy ciąg). Przegląd naukowy. Warszawa, 1844. N. 28. S. 24-25.

32. Żegota P. Słowniczek mniej zrozumiałych słów ruskich. Pieśni ludu ruskiego w Galiciji : w 2 t. Lwów, 1840. T. 2. S. $207-214$ 


\section{References (translated \& transliterated)}

1. Budziak, A. (2015). Apeliatyvni nazvy tvaryn u rukopysnykh slovnykakh Ivana Vahylevycha [Appellate names of animals in Ivan Vagilevich's handwritten dictionaries]. Beiträge der Europäischen Slavistichen Linguistik (Polyslav) 18 - Contribution to European Slavic Linguistics (Polyslav) 18. München - Berlin Leipzig - Washington [in Ukrainian].

2. Budziak, A. (2014). Apeliatyvni nazvy tvaryn u rukopysnykh slovnykakh Ivana Vahylevycha (nazvy ptakhiv) [Appeal names of animals in Ivan Vagilevich's handwritten dictionaries (bird names)]. Studia Methodologica. Ternopil, 39, 26-33 [in Ukrainian].

3. Budziak, A. (2015). Zakhidnoukrainski frazeolohichni odynytsi v leksykohrafichnykh pratsiakh XIX st. [Western Ukrainian phraseological units in the lexicographic works of the 19th century]. Ukrajinistika: minulost, přitomnost, budoucnost. III. Jazyk: kolektivni monografie věnovaná 20 výročí zahájení výuky ukrajinštiny jako studijního oboru na Filozofické fakultě Masarykovy univerzity v Brně - Ukrainian studies: past, present, future. III. Language: collective monograph dedicated to the 20th anniversary of the commencement of teaching Ukrainian as a field of study at the Faculty of Arts of Masaryk University in Brno. Brno, 69-76 [in Ukrainian].

4. Budziak, A. (2013). Karpatski topohrafichni nazvy v leksykohrafichnykh robotakh Ivana Vahylevycha [Carpathian topographic names in lexicographic works of Ivan Vagilevich]. W świecie Stowian. Szkice z dziejów leksykologii $i$ leksykografii. Księga dedykowana Profesorowi Wiesławowi Witkowskiemu w osiemdziesiata piata rocznice urodzin - In the world of Slavs. Sketches of the history of lexicology and lexicography. Book dedicated to Professor Wiestaw Witkowski on the eighty-fifth anniversary of his birth. H. Chodurska, A. Mażulis-Frydel, A. Radzik (Ed.). Krakow: Oficyna Wydawnicza «Impuls», 33-45 [in Ukrainian].

5. Vahylevych, I. (1996). [Idyotyzmy]. Dzendzelivsky Y. O. Ukrainsko-polskyi frazeolohichnyi slovnyk I. Vahylevycha. Yoho zh. Ukrainske i slovianske movoznavstvo - Ukrainian-Polish Phraseology Glossary by I. Vahylevych. Ukrainian and Slavic linguistics. Lviv: Atlas (Ukrainoznavcha biblioteka NTSh. part 6) [in Ukrainian].

6. Vahylevych, I. Slovar yazyka yuzhno-ruskoho 1834-1844 [Dictionary of the language of South Ruthenian 1834-1844]. Rosiiska nats. b-ka. Sankt-Peterburh - St. Petersburg Russian National library. F. 16. Spr. 23. 218 fold [in Ukrainian].

7. Halas, B. (2006). Z istorii morfonolohichnykh yavyshch ukrainskoi movy (na materiali rukopysnykh slovnykiv XIX - pochatku XX st.) [From the history of the morphonological phenomena of the Ukrainian language (on the material of handwritten dictionaries of the 19th - beginning of the 20th centuries)]. Visnyk Zaporizkoho natsionalnoho universytetu. Filolohichni nauky - Bulletin of Zaporizhzhya National University. Philological Sciences. Zaporizhzhia, 2, 48-58 [in Ukrainian].

8. Halas, B. K. (2000). Leksyka hutsulskykh i bukovynskykh hovirok u zapysakh I. Vahylevycha ta Ya. Holovatskoho [The vocabulary of Hutsul and Bukovyna dialects in the recordings of I. Vahylevych and Y. Holovatsky]. Slovianska filolohiia - Slavic Philology. Chernivtsi: Ruta, issue 93, $87-97$ [in Ukrainian].

9. Halas, B. K. (2003). Rukopysni slovnyky XIX - pochatku XX st. i tendentsii rozvytku ukrainskoi literaturnoi movy $\mathrm{v}$ Zakhidnii Ukraini [Handwritten dictionaries of the XIX - early XX centuries and trends in the development of Ukrainian literary language in Western Ukraine]. Materialy Mizhnarodnoi asotsiatsii ukrainistiv - Proceedings of the International Association of Ukrainianists. Chernivtsi: Ruta, 185-191[in Ukrainian].

10. Halas, B. K. (1980). Ukrainska narodna heohrafichna terminolohiia v rukopysnykh slovnykakh I polovyny XIX st. [Ukrainian folk geographical terminology in handwritten dictionaries of the first half of the nineteenth century]. Naukovo-tekhnichnyi prohres i problemy terminolohii - Scientific and technological progress and problems of terminology. Kyiv: Nauk. dumka, 57-59 [in Ukrainian].

11. Halas, B. K. (1995). F. S. Shymkevych yak leksykohraf i ukrainske slovnykarstvo (kinets XVIII - pochatok $X X$ st.) $[F . F$. Shymkevych as a lexicographer and Ukrainian lexikography (end of XVIII - beginning of $X X$ century)]. Uzhhorod: Polychka «Karpatskoho kraiu» [in Ukrainian].

12. Horetskyi, P. Y. (1963). Istoriia ukrainskoi leksykohrafii [History of Ukrainian lexicography]. Kyiv: Vydvo AN URSR [in Ukrainian].

13. Zbyr, I. (2005). Ukrainskyi folklor u rozvidkakh polskykh doslidnykiv na materiali «Pokuttia» Oskara Kolberga [Ukrainian Folklore in the Exploration of Polish Researchers by Oscar Kolberg's «Pokuttya»]. Problemy slovianoznavstva - Problems of Slavic Studies. Lviv, issue 55, 254-262 [in Ukrainian].

14. Kyrchiv, R. (1990). Etnohrafichno-folklorystychna diialnist «Ruskoi Triitsi» [Ethnographic and folklore activity of the Russian Trinity]. Kyiv: Nauk. dumka [in Ukrainian].

15. Kulchytska, T. (1999). Ukrainska leksykohrafiia XIII-XX st.: bibliohrafichnyi pokazhchyk [Ukrainian lexicography of the XIII-XX centuries: bibliographic index]. D. G. Grynchyshyn (Ed.). Lviv [in Ukrainian]. 
16. Lavrivskyi, I. Materiialy do slovaria russkaho (1822-1826 rr.): u 6 t. [Materials to the Ruthenian Dictionary (1822-1826)]. (Vols. 1-6). Lvivska nats. nauk. b-ka Ukrainy im. V. Stefanyka - Vasul Stefanyk Lviv National Scientific Library of Ukraine. F. 2. Op. 1. Spr. 331. Vol. 1: B-V. 698 p.; Vol. 2: D, Ye, Zh. 520 p.; Vol. 3: Z. 520 p.; Vol. 4: L-M. 196 p.; Vol. 5: S. 480 p.; Vol. 6: F, Ch. 400 p. [in Ukrainian].

17. Levytskyi, Y. (1830). Pryruchnyi slovár slavieno-pólskii, yly sobrániie Riechiénii slaviénskikh nieudób razumhitielnykh obritáiushchykhsia $v$ knýhakh tsierkovnykh, na jazyk polskii tolkóvanykh [The Handy Slavonic-Polish Dictionary]. Lvyhorod [in Ukrainian].

18. Matviias I. H. (1990). Ukrainska mova ta yiyi hovory [The Ukrainian language and its subdialects. Kyiv: Nauk. dumka [in Ukrainian].

19. Ohiienko, I. (Mytropolyt Ilarion) (1995). Istoriia ukrainskoi literaturnoi movy [History of Ukrainian literary language]. M. S. Tymoshyk (uporiad., avt. ist.-biohr. narysu ta prymit.). Kyiv: Lybid [in Ukrainian].

20. Perepyska Ivana Vahylevycha. Materiialy do istorii ukrainsko-cheskykh vzaiemyn v pershii polovyni XX st. [Correspondence of Ivan Vagilevich. Materials on the history of Ukrainian-Czech relations in the first half of the nineteenth century]. (1921). I. Bryk (vyd.). Lviv: Nakladom NTSh, Rozd. 1, 1-32 (Ukrainskoruskyi arkhiv. Vol. 15) [in Ukrainian].

21. Skomorovskyi, Y. Materiialy do slovaria ruskoho: u 5 t. [Materials to the Ruthenian Dictionary]. (Vols. 16). Lvivska nats. nauk. b-ka Ukrainy im. V. Stefanyka - Vasul Stefanyk Lviv National Scientific Library of Ukraine. F. 77. Op. 1. Spr. 305. Vol. 1: A-G. 146 fold.; Vol. 2: D-I. 137 fold.; Vol. 3: K-O. 181 fold.; Vol. 4: P. 220 fold.; Vol. 5: R-Shch. 184 fold.

22. Tkach, L. (2003). Narodnorozmovne dzherelo frazeolohizmiv spilnoho fondu ukrainskoi ta polskoi mov [Live folk source of phraseology of the joint fund of Ukrainian and Polish]. Ukrainska istorychna ta dialektna leksyka - Ukrainian historical and dialect vocabulary. Lviv: In-t ukrainoznavstva im. I. Krypiakevycha NAN Ukrainy, issue 4, 277-292 [in Ukrainian].

23. Budziak, A. (2014). Rękopiśmienna spuścizna stownikarska Iwana Wahylewycza [Ivan Vahylevych's manuscript heritage of dictionary work]. Krakow: Wyd-wo «Scriptum», 8 [in Polish].

24. Budziak, A. (2010). Zapożyczenia polskie w materiale ukraińskim XIX-wiecznego ukraińsko-polskiego słownika frazeologicznego Iwana Wahylewycza [Polish borrowings in Ukrainian material of the 19thcentury Ukrainian-Polish phraseology dictionary by Ivan Vahylevych]. Linguistica Copernicana Linguistics Copcrnicana. Torun: Wyd-wo Nauk. Uniw. Mikołaja Kopernika, 2 (4), 273-285 [in Polish].

25. Janów, J. (1937). Słowniczek huculski sprzed stulecia [Hutsul Glossary from a century ago]. Odbitka ze Sprawozdan Towarzystwa Naukowego we Lwowie - Print from the Reports of the Scientific Society in Lviv. Lviv, R.16, Z. 3, 1-12 [in Polish].

26. Linde, S. B. (1807-1814). Słownik języka polskiego [Polish Dictionary]. (Vols. 1-6). M. Bańko, M. Majdak, M. Czeszewski (Ed.). Warszaw: Drukarnia XX. Pijarów. Retrieved from http://www.leksyko grafia.uw.edu.pl/slowniki/37/slownik-jezyka-polskiego-warszawa-1807-1814.

27. Wagilewicz, J. (1841). Narzecze. Łemki. Mieszkańcy zachodniego wzgorza Karpat [Dialect. Lemky. Inhabitants of the western hill of the Carpathians ]. Naukova b-ka Lvivskoho nats. un-tu im. I. FrankaScientific Library of Ivan Franko National University of Lviv. Lviv, M-1173, Rozd. 5 [in Polish].

28. Wagilewicz, J. [Słowniczek]. Bojki. Szczep rusko-słowiański w Galicyi. [Bojky. A Ruthenian-Slavonic tribe in Galicya]. Lvivska nats. nauk. b-ka Ukrainy im. V. Stefanyka - Vasul Stefanyk Lviv National Scientific Library of Ukraine. F. 5. Op. 1. Spr. 4342, 19-21 [in Polish].

29. Wagilewicz, J. (1839). [Słowniczek]. Bojki, szczep rusko-słowiański w Galicyi. [Glossary. Bojky. A Ruthenian-Slavonic tribe in Galicya]. Naukova b-ka Lvivskoho nats. un-tu im. I. Franka - Scientific Library of Ivan Franko National University of Lviv. Lviv, M-1173, 18-19 [in Polish].

30. Wagilewicz, J. (1837). [Słowniczek]. Hucułowie. Mieszkańcy wschodniego wzgorza Karpat [Glossary. Hutsuly. Inhabitants of the eastern hill of the Carpathians]. Naukova b-ka Lvivskoho nats. un-tu im. I. Franka - Scientific Library of Ivan Franko National University of Lviv. Lviv, M-1173, 22-23 [in Polish].

31. Wagilewicz, J. (1844). [Słowniczek]. O mieszkańcach wschodniej części gór Karpackich (dalszy ciag). Przeglad naukowy. [Glossary. About inhabitants of the eastern part of the Carpathian (continuation). Scientific review]. Warszaw, 28, 24-25 [in Polish].

32. Żegota, P. (1840). Słowniczek mniej zrozumiałych słów ruskich. Pieśni ludu ruskiego w Galiciji [Glossary of less understandable Ruthenian words. Songs of the Ruthenian people in Galicia]. (Vols. 1-2). Lviv, Vol. 2, 207-214 [in Polish].

Статтю отримано 16.10.2019 року

Прийнято до друку 28.11 .19 року 